Abstracta Iranica Abstracta Iranica

Revue bibliographique pour le domaine irano-aryen

Volume 23 | 2002

Comptes rendus des publications de $\mathbf{2 0 0 0}$

\title{
« First fruits of Ryūkoku-Berlin joint project on the Turfan Iranian manuscripts ». Acta Asiatica, 78, (2000), pp. 71-85.
}

\section{Nicholas Sims-Williams}

\section{(2) OpenEdition Journals}

Édition électronique

URL : http://journals.openedition.org/abstractairanica/35157

DOI : 10.4000/abstractairanica.35157

ISSN : 1961-960X

Éditeur :

CNRS (UMR 7528 Mondes iraniens et indiens), Éditions de l'IFRI

\section{Édition imprimée}

Date de publication : 15 mai 2002

ISSN : 0240-8910

Référence électronique

Nicholas Sims-Williams, « « First fruits of Ryūkoku-Berlin joint project on the Turfan Iranian manuscripts ». Acta Asiatica, 78, (2000), pp. 71-85. », Abstracta Iranica [En ligne], Volume 23| 2002, document 29, mis en ligne le 08 février 2010, consulté le 25 septembre 2020. URL : http:// journals.openedition.org/abstractairanica/35157 ; DOI : https://doi.org/10.4000/abstractairanica. 35157

Ce document a été généré automatiquement le 25 septembre 2020.

Tous droits réservés 


\title{
« First fruits of Ryūkoku-Berlin joint project on the Turfan Iranian manuscripts ». Acta Asiatica, 78, (2000), pp. 71-85.
}

\author{
Nicholas Sims-Williams
}

1 The project referred to in the title is concerned with manuscript fragments bearing a Chinese text on one side and Middle Iranian text on the other. The author demonstrates that fragments in different collections (especially Berlin and Kyoto, but also St Petersburg and Helsinki) can sometimes be joined and edits some of the resulting Sogdian texts : 1. part of the "Sermon on the Light Nous»; 2. part of the Manichaean "Church history». The final part of the article offers further improvements in the interpretation of notes scribbled by Sogdian and Turkish Manichaeans on books which they had read or owned [cf. Abs. Ir. 17-19, n ${ }^{\circ} 98$ ].

\section{INDEX}

Thèmes : 2.1. Langues anciennes

\section{AUTEURS}

NICHOLAS SIMS-WILLIAMS

Université de Londres - Grande-Bretagne 